\title{
Estimation of additive and non-additive effects on milk production traits in Iranian Holstein crossbred population
}

\author{
Abolfazl Ghorbani and Ramin Salamatdoustnobar \\ Department of Animal Science, Islamic Azad University, Shabestar Branch, Shabestar, Iran
}

\begin{abstract}
Direct and interactive effect (individual and maternal heterosis) was estimated using data from rotational crosses between Holsteins with Iranian native breeds. Traits of interest were milk yield, fat yield, fat percent and milk days. Complete data were available on 155240 animals from 1991 through 2003. Direct additive's effect, individual heterosis, maternal heterosis and recombination (interactions between presences of Holstein gene in two parents) effects were estimated by multiple regression method in SAS 8.2 with mixed models procedure. The least squares means of milk yield, fat yield, fat percent and milk days were $2722.68 \pm 1541.12 \mathrm{~kg}, 122.97 \pm 47.40 \mathrm{~kg}, 3.97 \pm 0.73$ percent and $260.10 \pm 89.51$ days respectively. All direct and indirect genetic effects are significant in milk and milk days traits $(P<0.05)$. Individual and maternal heterosis and recombination effect are not significant on fat yield and fat percent traits. The individual and recombination effect were negative effect on milk yield. The result suggested that the Holstein is a favourable breed for crossbreeding program in developing country as Iran.
\end{abstract}

Keywords: crossbreeding, heterosis, Iran, milk

\section{Introduction}

With the increasing population in worldwide and need to increase milk production, the introduction of high-yielding breeds (i.e. Holstein-Friesian) plays an important role in protein needs supplying. In developing countries, the performance of these breeds is often negatively affected due to genotype-environment interactions (Bondoc et al. 1989, Rege 1991, Smith 1988, Ojango et al. 2005). One of the best methods for solving this problem could be crossbreeding. Crossbreeding as a mating system optimizes the additive genetic and nonadditive (heterotic) breed effects of Bos taurus and Bos indicus cattle in sustainable breeding systems (Gregory \& Cundiff 1980). The design of optimal program and genetic manipulation would be more precise if the proportion of the genetic variance that is attributable to additive and non-additive gene action were known. In addition, knowledge of the maternal contribution to the performance of the offspring is necessary in planning sound breeding programs (Cassady et al. 2002, Solnker 1993, Vostry et al. 2008). The Iran dairy industry was based on approximately 1.4 million lactating cows in 2008. Breed composition of the herds was $65 \%$ Holstein-Friesian, $27 \%$ crossbred and $7 \%$ native cattle (Naji 1996). Despite the high population of crossbred's cattle, a little estimates of breed and heterosis effects on productive traits have been reported, Rekui (2000) carried out first estimates of heterosis effects on the 
Isfahan crossbred cattle and reported significant effect on production traits. The objectives of this study were to estimate direct and maternal heterosis effects on production traits.

\section{Materials and methods}

A total of 155240 animal records were collected from 1991 through 2003 from Holstein crossbred population by animal breeding centre of agricultural ministry, Iran. Data includes all province herds. For each cow milk yield $(\mathrm{kg})$, fat yield $(\mathrm{kg})$ fat percent and milk days traits information and breed composition were known. Editing data included checks on breed code of sires and progeny. Pedigree data were iteratively retrieved in seven loops for all cows with records and for their parents no additional pedigree was after this time. Ninety-five percent of the pedigree was found after three loops; give a total of 12445 animals in model. Nine genetic groups were defined according to percentage of imported breed genes at intervals $12.5 \%$.

Excel 2003 (Microsoft Corporation, Redmond, WA, USA), SPSS 9 (SPSS Inc., Chicago, IL, USA) and FoxPro 2.6 (Microsoft Corporation, Redmond, WA, USA) were used for editing data and SAS 8.2 (SAS Institute Inc., Cary, NC, USA) for analysis and parameter estimation.

\section{Statistical analyses}

Records were analysed with following model that proposed by Van Der Werf \& De Boer (1989):

$$
y_{i j k l m n o p}=\mu+L_{i}+H_{j}+(Y S)_{k}+g_{l}+H_{m} t_{m}+\operatorname{Rec}_{n}+\text { MHet }_{o}+a_{p}+e_{i j k l m n o p}
$$

where $\mu$ is population mean, $L_{i}$ is lactation number $i=1 \ldots 8, H_{j}$ and $Y_{s k}$ are fixed environmental effects of herd and year season with $j=1 . .295$ and $k=1 . . .4, g$, is fraction of Holstein gene in crossbred progeny with $l=1 \ldots 8$ that equal to $\left[\left(\mathrm{P}_{s}+\mathrm{P}_{d}\right) / 2\right]\left(\mathrm{P}_{\mathrm{s}}\right.$ and $\mathrm{P}_{\mathrm{d}}$ are imported genes percent in two parent), $H_{e t m}$ is hetrosis percent in progeny is equal to degree of heterozygosity of animal, $R_{\text {ecn }}$ is interactions between presence of imported gene in two parents, $M_{\text {heto }}$ is maternal hetrosis, $a_{p}$ is the additive genetic effect of cow making record; and $e_{i j k l m n o p}$ is a residual effect. Regression analysis was used here to efficiently estimate genetic effects given the mating systems employed in this study. Procedures for mixed models (PROC MIXED) were used to estimate breed direct, individual, maternal heterosis and breed-combination effects.

\section{Results}

The overall least squares means for milk yield, fat yield, fat percent and milk-days traits were $2722.68 \pm 1541.12 \mathrm{~kg}, 122.97 \pm 47.40 \mathrm{~kg}, 3.97 \pm 0.73$ percent and $260.10 \pm 89.51$ days respectively which were in agreement with the means reported by Rekui (2000) and Naji (1996) in Holstein Friesian $\times$ Golpaigani cows. But, means slightly higher than those in the present study. These variations are to be expected as probable consequences of feeding and management changes, as well as changes in the genetic composition of the herd over the study.

The linear regression approach was used to estimate of additive and non-additive effects to different traits. This statistical method will be able to separating component parts of performance and can be used to predict performance of various crossbred animals.

Estimation of additive and non-additive effects on traits is given in Table 1. The effects are 
presented with their SE and $P$-value obtained directly from the regression models. The direct additive's effect on milk yield, fat percent and milk days traits were significant $(P<0.05)$ but in fat yield trait is no significant $(P>0.05)$. The value of this effect only on fat percent traits was negative. This situation arises due to the fact that Holstein has low fat percent compared with the native breeds. This result is not supported by the previous work of Rekui (2000) who worked with crossbred Holstein-Golpaigani cows and reported that direct effect on milk yield, fat yield and fat percent were $20.86,0.712 \mathrm{~kg}$ and 0.041 percent receptivity. Significant regression coefficients were estimated for the effect of individual heterosis on milk yield and milk-days traits $(P<0.001)$. The individual heterosis estimation on all traits, expect milk days trait, are negative.

Table 1

Additive and non-additive effects in different traits

\begin{tabular}{lcccc}
\hline & direct additive's effect & Individual hetrosis & Maternal hetrosis & Recombination effect \\
\hline Milk & $10.14 \pm 0.66$ & $-1.69 \pm 0.42$ & $3.34 \pm 0.895$ & $-6.24 \pm 1.088$ \\
& $(<0.0001)$ & $(<0.0001)$ & $(<0.0001)$ & $(0.002)$ \\
Fat yield & $0.0161 \pm 0.0161$ & $-0.00017 \pm 0.01$ & $-0.0078 \pm 0.022$ & $0.012 \pm 0.026$ \\
& $(0.7040)$ & $(0.9894)$ & $(0.7137)$ & $(0.6435)$ \\
Fat percent & $-0.000089 \pm 0.0047$ & $-0.00026 \pm 0.00031$ & $0.0012 \pm 0.0013$ & $-0.0016 \pm 0.0014$ \\
& $(0.0116)$ & $(0.3618)$ & $(0.3806)$ & $(0.2596)$ \\
Milk days & $0.241 \pm 0.045$ & $0.058 \pm 0.029$ & $-0.135 \pm 0.061$ & $0.242 \pm 0.074$ \\
& $(<0.0001)$ & $(0.0097)$ & $(0.0041)$ & $(<0.0001)$ \\
\hline
\end{tabular}

The maternal heterosis effects are significant on milk yield and milk day's traits but unlike Individual heterosis are positive in milk yield and fat percent traits and negative for other. Recombination effect is the breakup of epistatic effects during meiosis to form non parental in the locus combinations of alleles in gametes of crossbred parents (Dickerson 1973) or in the other hand it originate either through dominance effects, from interactions between native breeds and Holstein genes within loci, or epistatic effects from interactions between loci (Van Der Werf \& De Boer 1989). This effect had same trend with maternal heterosis in significantly but in milk yield and fat percent traits were negative. Positive heterosis on milk yield were reported by MacDowell \& McDaniel (1968), Beckett \& Ludwick (1979), Katpatal (1977), Van Der Werf \& De Boer (1989), Rincon et al. (1982), Ahlborn-Breier \& Hohenboken (1991), Kress et al. (1996), Rekui (2000), Vanraden \& Sanders (2003) but Soldatov \& Dutsheev (1991) and Wang et al. (1992) reported negative heterosis. Beckett \& Ludwick (1979), Rincon et al. (1982), Naji (1996) and Rekui (2000) reported positive heterosis on fat yield and MacDowell \& McDaniel (1968) and Van Der Werf (1989) reported negative heterosis on fat yield. However Beckett \& Ludwick (1979), Rincon et al. (1982) and Ahlborn-Breier \& Hohenboken (1991) reported negative heterosis on fat percent trait and Rekui (2000) reported positive heterosis. Positive maternal heterosis on milk yield and fat yield traits reported by Kress et al. (1996) and Rekui (2000) but Ahlborn-Breier \& Hohenboken (1991) and Rekui (2000) reported negative maternal heterosis on fat percent. Contradictory results in papers may be due to difference of native and imported breeds used in crossbreeding program and number and breed composition of animal in analysis procedure. 


\section{Discussion}

Results of this study are consistent with the results of further studies because most studies on the Holstein crossbred populations have reported positive heterosis while in this study for Holstein crossbreeds has been estimated negative heterosis in many traits. Recombination effect that shown interaction between imported and native genes in cross animal was same trend with individual heterosis. Totally, results of this study showed that entrance of new Bos taurus breeds in Iranian native cattle population has increased production economic traits, although this effect on the fat yield trait was not significant.

Crossbreeding is yet another tool in the genetic improvement and like anything else can be very profitable if understood and used correctly.

\section{References}

Ahlborn-Breier G, Hohenboken WD (1991) Additive and nonadditive Genetic effects on milk production in dairy cattle: Evidence for major individual heterosis. J Dairy Sci 74, 592-602

Beckett RC, Ludwick TM (1979) Specific and general combining abilities for production and reproduction among lines of Holstein cattle. J Dairy Sci 62, 613-620

Bondoc OC, Smith C, Gibson JP (1989) A review of breeding strategies for genetic improvement of dairy cattle in developing countries. Anim Breed Abstr 57, 819-829

Cassady JP, Young LD, Leymaster KA (2002) Heterosis and recombination effects on pig reproductive traits. J Anim Sci 80, 2303-2315

Dickerson GE (1973) Inbreeding and heterosis in animals. In: Proc Anim Breed Genet Symp in Honor of Dr. Jay L. Lush. Am Soc Anim Sci, Champaign, IL, USA, 54-77

Gregory KE, Cundiff LV (1980) Crossbreeding in beef cattle: Evaluation of systems. J Anim Sci 51, 1224-1242

Katpatal BG (1977) Daru cattle crossbreeding in India. The results of the all India Coordinated. Research project on cattle, World Anim Rev 23, 2-9

Kress DD, Doornbos DE, Anderson DC, Davis KC (1996) Genetic components for milk production of Tarentaise, Hereford and Tarentaise $x$ Hereford cows. J Anim Sci 74, 2344-2348

McDowell RE, McDaniel BT (1968) Interbreed matings in dairy cattle. I.Yield traits, feed efficiency, type and rate of milking. J Dairy Sci 51, 767-777

Naji ZA (1996) Study of Golpaigani crossbred dairy cattle in rural conditions. MSc thesis, Department of Animal Science, University of Tehran, Iran

Ojango JMK, Ducrocq V, Pollott GE (2005) Survival analysis of factors affecting culling early in the productive life of Holstein-Friesian in Kenya. Livest Prod Sci 92, 317-322

Rege JEO (1991) Genetic analysis of reproductive and productive performance of Friesian cattle in Kenya I Genetic and phenotypic parameters. J Anim Breed Genet 108, 412-423

Rekui M (2000) Individual and maternal heterosis and genetic parameter estimation for production and reproduction traits in the Isfahan crossbred population. MSc thesis, Department of animal science, University of Tarbiat Modares, Iran

Rincon EJ, Schermerhorn EC, McDowell RE, McDaniel BT (1982) Estimation of genetic effects on milk yield and constituent traits in crossbred dairy cattle. J Dairy Sci 65, 848-856

Smith C (1988) Genetic improvement of livestock in developing countries using nucleus bredding units. World Anim Rev 65, 2-10

Soldatov AP, Duisheev AN (1991) [Age variations in milk production and length of productive lifetime of cows of the Ala-Tau breed depending on genetic line]. Vestnik Sel'skokhozyaistvennoi Nauki 4, 145-147 [in Russian] 
Sölkner J (1993) Choice of optimality criteria for the design of crossbreeding experiments. J Anim Sci 71, 2867-2873

Van Der Werf JHJ, De Boer W (1989) Influence of nonaddtive effect on estimation of genetic parameters in dairy cattle. J Dairy Sci 72, 2606-2614

VanRaden PM, Sanders AH (2003) Economic merit of crossbred and purebred US dairy cattle. J Dairy Sci 86, 1036-1044

Vostry L, Jakubec V, Schlote W, Bjelka M, Bezdicek J, Majzlik I (2008) Analysis of population and heterosis effects in crossbred cattle of Czech Fleckvieh and Beef Simmental parentage for growth traits. Arch Tierz $51,207-215$

Wang N, Vandepitte W, Nouwen J, Carbonez R (1992) Crossbreeding of Holstein Friesian, Brown Swiss and Sanga breeds in Zaire. Milk production, growth rate, calving interval and body size. Rev Méd Vét Pays Tropic 45, 340-356

Received 19 July 2011, accepted 13 June 2012.

Corresponding author:

Abolfazl Ghorbani

email: abolfazlgorbani@gmail.com

Department of Animal Science, Shabestar Branch, Islamic Azad University, Shabestar, Iran 